\title{
The use of metalaxyl and potassium phosphonate, mounds, and organic and plastic mulches, for the management of Phytophthora root rot of papaya in far northern Queensland
}

\author{
L. L. Vawdrey ${ }^{\mathrm{A}, \mathrm{C}}$, K. E. Grice ${ }^{\mathrm{B}}$, R. A. Peterson ${ }^{\mathrm{B}}$ and J. De Faveri ${ }^{\mathrm{B}}$ \\ ${ }^{A}$ Queensland Horticulture Institute, Department of Primary Industries, Centre for Wet Tropics Agriculture, \\ South Johnstone, Qld 4859 Australia. \\ ${ }^{\mathrm{B}}$ Queensland Horticulture Institute, Department of Primary Industries, Centre for Tropical Agriculture, Mareeba, \\ Qld 4880 Australia. \\ ${ }^{\mathrm{C}}$ Corresponding author; email: lynton.vawdrey@dpi.qld.gov.au
}

\begin{abstract}
Options for the control of root rot of papaya caused by Phytophthora palmivora were evaluated in two field experiments in far northern Queensland, Australia. In the first experiment, foliar sprays of potassium phosphonate $(10 \mathrm{~g} / \mathrm{L})$ applied fortnightly reduced the incidence of root rot by $47 \%$. Metalaxyl granules $\left(1.25 \mathrm{~g} / \mathrm{m}^{2}\right)$ applied every 6 weeks, and metalaxyl granules $\left(1.25 \mathrm{~g} / \mathrm{m}^{2}\right)$ applied at transplanting combined with fortnightly foliar sprays of potassium phosphonate $(10 \mathrm{~g} / \mathrm{L})$ also provided a level of control. Fortnightly foliar sprays of potassium phosphonate $(5 \mathrm{~g} / \mathrm{L})$ and monthly foliar sprays of potassium phosphonate $(5$ and $10 \mathrm{~g} / \mathrm{L})$, and fortnightly and monthly soil drenches with potassium phosphonate $(1$ and $2 \mathrm{~g} / \mathrm{L})$ had no significant effect $(P>0.05)$ on the incidence of root rot. In the second experiment, growing papaya on $0.75 \mathrm{~m}$ mounds reduced the incidence of root rot by $38.4 \%$ and significantly increased fruit yield. Soil covers of $2 \mathrm{~m}$ wide plastic mulch and organic mulch in combination with $0.75 \mathrm{~m}$ mounds, further reduced plant losses by 20 and $10 \%$, respectively. Plastic mulch on flat ground was as effective as the mounded treatments in reducing the incidence of root rot and increasing yield.
\end{abstract}

Additional keywords: Carica papaya, soil covers.

\section{Introduction}

The northern Queensland papaya industry (latitudes $16.48^{\circ} \mathrm{S}$ to $17.26^{\circ} \mathrm{S}$ ), which comprises some $90 \%$ of all papaya (Carica papaya) grown in Australia, consists mainly of farms which are no more than 2 ha in size. However, the soilborne pathogen Phytophthora palmivora, which causes a decay of the tap root and eventual death of the plant, is widespread in the growing area (Vawdrey 2001). Recommendations for the control of the disease involve papaya being planted on land not previously planted to papaya (Chay-Prove 2000). This situation has been a major constraint to the expansion of the papaya industry in the region.

Diseases caused by Phytophthora spp. have been controlled with the use of copper-based protectant fungicides, or by systemic fungicides such as carbamates, cymoxamils, acylanilides and phosphonates (Cohen and Coffey 1986). These chemicals have been applied as soil drenches, sprays, trunk paint or by trunk injection (Erwin and Ribeiro 1996). Metalaxyl and potassium phosphonate are two chemicals used extensively to control Phytophthora-induced diseases of many crops (Schwinn and Staub 1987). Metalaxyl $\left(1.25 \mathrm{~g} / \mathrm{m}^{2}\right)$ had provided a level of control of root rot of papaya in a previous field experiment (R. Peterson, unpublished data).

The conventional method of growing papaya in all growing areas has involved planting seedlings into flat ground (Dunn 2001). Duniway (1979) concluded that the most important environmental factor influencing Phytophthora-related root disease, was the duration of saturation or near-saturation of soil. Soil conditions such as these are known to favour the rapid formation of sporangia and infectious zoospores and a high level of disease. Although the most suitable papaya-growing soils in far north Queensland are well-drained loams, these soils are likely to remain saturated for prolonged periods during heavy wet seasons. Improving soil drainage through mounding and mulch application has been used successfully in avocado to manage Phytophthora root rot (Broadley 1992; Pegg and Whiley 1987). 
Table 1. Effect of metalaxyl and potassium phosphonate alone and in combination, at various rates, application times and methods of application on the incidence of Phytophthora root rot of papaya

\begin{tabular}{|c|c|c|c|c|}
\hline \multirow[t]{2}{*}{ Treatment } & \multirow{2}{*}{$\begin{array}{l}\text { Method of application and } \\
\text { rate of a.i. }\end{array}$} & \multirow[t]{2}{*}{ Treatment interval } & \multicolumn{2}{|c|}{$\%$ papaya infection ${ }^{\mathrm{A}}$ at } \\
\hline & & & 4 June & 8 July \\
\hline Untreated & - & - & $80.0 \mathrm{ab}$ & $90.0 \mathrm{ab}$ \\
\hline Phosphonate & Drench $1 \mathrm{~g} / \mathrm{L}$ & Monthly & $85.0 \mathrm{a}$ & $97.5 \mathrm{a}$ \\
\hline Phosphonate & Drench $2 \mathrm{~g} / \mathrm{L}$ & Fortnightly & $77.5 \mathrm{abc}$ & $85.0 \mathrm{ab}$ \\
\hline Phosphonate & Spray $5 \mathrm{~g} / \mathrm{L}$ & Monthly & $70.0 \mathrm{abcd}$ & $85.0 \mathrm{ab}$ \\
\hline Phosphonate & Drench $2 \mathrm{~g} / \mathrm{L}$ & Monthly & $65.0 \mathrm{abcd}$ & $90.0 \mathrm{ab}$ \\
\hline Phosphonate & Spray $10 \mathrm{~g} / \mathrm{L}$ & Monthly & $55.0 \mathrm{bcde}$ & 65.0 bcde \\
\hline Phosphonate & Spray 5 g/L & Fortnightly & $55.0 \mathrm{bcde}$ & $77.5 \mathrm{abcd}$ \\
\hline Phosphonate & Drench $1 \mathrm{~g} / \mathrm{L}$ & Fortnightly & $50.0 \mathrm{cde}$ & $75.0 \mathrm{abcd}$ \\
\hline Metalaxyl & Granules $0.5 \mathrm{~g} / \mathrm{m}^{2}$ & 6 weeks & $50.0 \mathrm{cde}$ & $82.5 \mathrm{abc}$ \\
\hline Metalaxyl & Granules $1.25 \mathrm{~g} / \mathrm{m}^{2}$ & 6 weeks & $45.0 \mathrm{de}$ & $57.5 \mathrm{cde}$ \\
\hline Metalaxyl + & Granules $1.25 \mathrm{~g} / \mathrm{m}^{2}$ & At transplanting & & \\
\hline Phosphonate & Spray $10 \mathrm{~g} / \mathrm{L}$ & Fortnightly & $35.0 \mathrm{e}$ & $55.0 \mathrm{de}$ \\
\hline Phosphonate & Spray $10 \mathrm{~g} / \mathrm{L}$ & Fortnightly & $27.5 \mathrm{e}$ & $42.5 \mathrm{e}$ \\
\hline
\end{tabular}

${ }^{\mathrm{A}}$ Means in the same column followed by the same letter are not significantly different $(P>0.05)$.

This paper reports a field experiment that tested metalaxyl granules and potassium phosphonate soil drenches and foliar sprays at varying rates and frequency of application for the control of Phytophthora root rot of papaya. In a second field experiment, mounds and organic and plastic mulches with, and without, metalaxyl were examined for their effectiveness in reducing root rot of papaya.

\section{Methods}

Two experiments were conducted on separate growers' properties. P. palmivora was recovered from papaya plants showing severe symptoms of root rot at both sites just prior to commencing the experiments.

\section{Evaluation of metalaxyl and potassium phosphonate}

Site description and experimental design. The experiment was established in January 1997 in a kraznozem soil on a commercial papaya property at Innisfail, Queensland, Australia. Treatments (Table 1) consisted of metalaxyl (Ridomil 50G) and potassium phosphonate (Fosject 200) used alone and in combination, applied at various rates and frequency of application. The site was divided into 52 plots (each $18 \mathrm{~m} \times 4 \mathrm{~m}$ ) consisting of 13 treatments and four replications arranged as a randomised complete block. Plots contained a single row of 12 plant positions (ten datum plant positions with one guard plant position at each end) with a single row of unsprayed plants separating treatments.

Plant establishment. Eight-week-old papaya seedlings of the cultivar Hybrid 29, which is highly susceptible to Phytophthora root rot, were transplanted from pasteurised potting mix into $1 \mathrm{~m}$ wide, $20 \mathrm{~cm}$ high flat beds in the experimental area on 9 January 1997. As the hybrid used was dioecious, three or four plants were planted at each plant position to allow the establishment of $90 \%$ female plants in each plot. Plants were thinned 11 weeks after transplanting to one plant per position at flowering, when the sex of the plant could be determined. Plants were irrigated as required using a single line of dripper irrigation. All plots received a basal fertiliser application of Crop King 55 (13.2\% $\mathrm{N}, 14.7 \% \mathrm{P}, 12.3 \% \mathrm{~K}, 1.5 \% \mathrm{~S})$ and superphosphate $(8.8 \% \mathrm{P}, 20 \% \mathrm{Ca}$, $11 \% \mathrm{~S}$ ) at the rate of 55 and $110 \mathrm{~kg} / \mathrm{ha}$, respectively, and dolomite $\left(16.5 \% \mathrm{CaCO}_{3}\right.$ and $\left.10 \% \mathrm{MgCO}_{3}\right)$ at $1100 \mathrm{~kg} / \mathrm{ha}$, with a further side dressing of Crop King 55 at $110 \mathrm{~kg} / \mathrm{ha}$ at flowering.

Treatment application and data collection. Potassium phosphonate treatments (Table 1) were applied to the appropriate potted plants 14 days prior to transplanting to the field. All field applications of metalaxyl and potassium phosphonate (Table 1) were commenced immediately following transplanting. The first six foliar sprays of potassium phosphonate were made with a knapsack and the remaining seven applications were made with a motorised shoulder-mounted misting unit (Efco). Spray volumes increased from 52 to $208 \mathrm{~L} / \mathrm{ha}$ as the plants grew. Phosphonate drench treatments were diluted in water (1389 $\mathrm{L} / \mathrm{ha}$ ) and applied with a watering can along the centre of the beds of the appropriate plots. Metalaxyl (Ridomil, $50 \mathrm{~g} / \mathrm{kg}$ ) treatments were broadcast evenly on the surface of the beds and lightly raked into the soil. Plant infection counts were recorded as plants showed symptoms of wilting resulting from a decay of the tap root. Diseased plants were cut at ground level and moved to the inter-row. Samples of diseased roots were obtained from each root rot-affected plant to identify the causal organism. Sections of diseased roots were surface sterilised in $70 \%$ methanol for $1 \mathrm{~min}$, blotted dry with sterile paper then transferred to potato-dextrose agar (PDA) plus streptomycin sulphate and the Phytophthora selective medium $\mathrm{P}_{10} \mathrm{ARP}+\mathrm{H}$ (Jeffers and Martin 1986). Plant heights $(\mathrm{cm})$ were recorded 9 weeks after transplanting. The experiment was completed 28 weeks after the transplanting of papaya.

Data analysis. Analysis of variance was used to analyse the plant heights and the percentage papaya infection data.

\section{Use of mounds and soil-surface mulches}

Site description and experimental design. The experiment was established on 13 January 1997 in a kraznozem soil on a commercial papaya property at Innisfail, Queensland, Australia. The experiment was set up as a split/split plot in a randomised complete block design. There were three replicates each with two whole plots to which the mounding/flat ground treatments were applied. Each whole plot was divided into three subplots to which the cover treatments plastic mulch, organic mulch or nil cover were applied. Each subplot was then divided into two sub-subplots where metalaxyl or a nil treatment was applied. There were ten datum plants and two guard plants per sub-subplot.

Treatment application. On 8 January 1997, the experimental site was deep-ripped and rotary-hoed and mounds $(0.75 \mathrm{~m}$ high) each $1.5 \mathrm{~m}$ wide and $18 \mathrm{~m}$ long were formed in the appropriate plots. Metalaxyl 
Table 2. Plant heights of papaya grown on mounds or flat ground, with organic and plastic mulches

\begin{tabular}{lccl}
\hline Treatment & \multicolumn{3}{c}{ Plant height $(\mathrm{cm})^{\mathrm{A}}$} \\
& 11 March & 22 April & 20 May \\
\hline Mound/plastic mulch & $78.0 \mathrm{a}$ & $119.0 \mathrm{ab}$ & $176.0 \mathrm{a}$ \\
Mound/organic mulch & $67.0 \mathrm{a}$ & $95.0 \mathrm{c}$ & $142.0 \mathrm{abcd}$ \\
Mound/bare soil & $88.0 \mathrm{a}$ & $107.0 \mathrm{abc}$ & $137.0 \mathrm{bcd}$ \\
Flat/plastic mulch & $68.0 \mathrm{a}$ & $109.0 \mathrm{abc}$ & $161.0 \mathrm{ab}$ \\
Flat/organic mulch & $46.0 \mathrm{~b}$ & $65.0 \mathrm{~d}$ & $101.0 \mathrm{e}$ \\
Flat/bare soil & $73.0 \mathrm{a}$ & $88.0 \mathrm{c}$ & $108.0 \mathrm{de}$ \\
\hline
\end{tabular}

${ }^{\mathrm{A}}$ Means in the same column followed by the same letter are not significantly different $(P>0.05)$.

(Ridomil, $50 \mathrm{~g} / \mathrm{kg}$ ) treatments were broadcast evenly on the surface of the beds and lightly raked into the soil just prior to the application of the soil-surface mulches. Plots treated with organic mulch were covered to a depth of $7.5 \mathrm{~cm}$ with composted shredded tree bark obtained from the local council waste depot. The plastic mulch treatments (Table 2), which consisted of $2 \mathrm{~m}$ wide black plastic sheets, were laid and then painted white to prevent sunscald damage to the newly planted seedlings.

Plant establishment. Eight-week-old papaya seedlings (Hybrid 29) were transplanted from pasteurised potting mix into plots in the experimental area on 13 January 1997. Plants were thinned to 1 plant per position at flowering when the sex of the plant could be determined. Plants were irrigated as required using dripper lines positioned either side of the planting line. All plots received a basal fertiliser application of Crop King 55 and superphosphate at the rate of 55 and $110 \mathrm{~kg} / \mathrm{ha}$, respectively, and dolomite at $1100 \mathrm{~kg} / \mathrm{ha}$. Two applications of urea (39 $\mathrm{kg} / \mathrm{ha}$ ) were applied through the irrigation system during the growing of the crop.

Data collection. Plant heights $(\mathrm{cm})$ were recorded at 8,13 and 17 weeks after transplanting. Plant infection counts were recorded as plants showed symptoms of wilting resulting from the decay of the tap root. Diseased plants were cut at ground level and moved to the inter-row. Samples of diseased roots were obtained from each root rot-affected plant and isolations carried out as described previously. On 6 November, all fruit with a diameter greater than $7 \mathrm{~cm}$ was harvested and the total fruit number and total fruit weight per plot assessed.

Data analysis. Analysis of variance was used to analyse the plant heights and the percentage papaya infection data. The total fruit count per plot and the total fruit weight per plot were also analysed using ANOVA after a $\log _{\mathrm{e}}(x+1)$ transformation.

\section{Results}

\section{Evaluation of metalaxyl and potassium phosphonate}

Potassium phosphonate used as a foliar spray at 5 and $10 \mathrm{~g} / \mathrm{L}$ caused some bleaching of foliage of newly transplanted seedlings. Although growth was initially restricted, affected plants continued to grow. Plant height measurements showed there was no significant difference $(P>0.05)$ between treatments.

By 4 June, there was a high incidence of root rot-affected plants in many plots and, in untreated plots, $80 \%$ of plants were affected with root rot (Table 1). P. palmivora was recovered from all root rot-affected plants. Fortnightly foliar sprays of potassium phosphonate $(10 \mathrm{~g} / \mathrm{L})$ alone and in combination with metalaxyl $\left(1.25 \mathrm{~g} / \mathrm{m}^{2}\right)$ at transplanting were more effective $(P<0.05)$ at reducing root rot than foliar sprays of potassium phosphonate $(5 \mathrm{~g} / \mathrm{L})$ applied monthly, and soil drenches of potassium phosphonate applied fortnightly ( $2 \mathrm{~g} / \mathrm{L})$ and monthly ( 1 and $2 \mathrm{~g} / \mathrm{L})$. Applying metalaxyl granules $\left(1.25 \mathrm{~g} / \mathrm{m}^{2}\right)$ at transplanting and every 6 weeks thereafter was more effective $(P<0.05)$ at reducing root rot than potassium phosphonate drenches applied fortnightly $(2 \mathrm{~g} / \mathrm{L})$ and monthly ( 1 and $2 \mathrm{~g} / \mathrm{L})$.

The final disease assessment conducted on 8 July (Table 1) showed that the incidence of root rot was very high with $90 \%$ of plants affected in untreated plots. Plots sprayed fortnightly with $10 \mathrm{~g} / \mathrm{L}$ potassium phosphonate had significantly fewer plants affected with root $\operatorname{rot}(P<0.05)$ than all other plots except those sprayed monthly with potassium phosphonate $(10 \mathrm{~g} / \mathrm{L})$, fortnightly with potassium phosphonate $(10 \mathrm{~g} / \mathrm{L})$ in combination with metalaxyl granules $\left(1.25 \mathrm{~g} / \mathrm{m}^{2}\right)$ at transplanting, and plots treated every 6 weeks with metalaxyl granules $\left(1.25 \mathrm{~g} / \mathrm{m}^{2}\right)$.

\section{Use of mounds, and organic and plastic mulches}

Some seedlings died within 1-2 weeks of transplanting. Rhizoctonia solani was recovered from basal stem lesions on a few plants using PDA plus streptomycin sulphate culture medium but the cause of most plant deaths was most likely due to physical damage to the taproot at transplanting.

Table 3. Effect of growing papaya on mounds or flat ground, with or without organic and plastic mulches, on the incidence of Phytophthora root rot, fruit weight and fruit number

\begin{tabular}{llcc}
\hline Treatment & $\begin{array}{c}\text { Total fruit number } \\
\text { per plot }^{\mathrm{AB}}\end{array}$ & $\begin{array}{c}\text { Total fruit weight } \\
\text { per plot }(\mathrm{kg})\end{array}$ & $\begin{array}{c}\text { \% } \\
\text { \% papaya infection } \\
\text { at harvest }^{\mathrm{B}}\end{array}$ \\
\hline Mound/plastic mulch & $5.04 \mathrm{a}(153.75)$ & $4.68 \mathrm{a}(106.52)$ & $8.33 \mathrm{a}$ \\
Mound/organic mulch & $3.87 \mathrm{~b}(47.02)$ & $3.36 \mathrm{~b}(27.67)$ & $18.33 \mathrm{a}$ \\
Mound/bare soil & $3.89 \mathrm{~b}(48.10)$ & $3.39 \mathrm{~b}(28.62)$ & $28.33 \mathrm{a}$ \\
Flat/plastic mulch & $4.58 \mathrm{ab}(96.80)$ & $4.17 \mathrm{a}(63.40)$ & $20.00 \mathrm{a}$ \\
Flat/organic mulch & $0.96 \mathrm{c}(1.62)$ & $0.67 \mathrm{c}(0.94)$ & $88.33 \mathrm{~b}$ \\
Flat/bare soil & $1.47 \mathrm{c}(3.36)$ & $1.08 \mathrm{c}(1.93)$ & $66.67 \mathrm{~b}$ \\
\hline
\end{tabular}

${ }^{\mathrm{A}} \log _{\mathrm{e}}(x+1)$ transformed data; back-transformed means are given in parentheses.

${ }^{\mathrm{B}}$ Means in the same column followed by the same letter are not significantly different $(P>0.05)$. 
Planting sites where all plants had died were replanted within 4 weeks of the initial transplanting.

By 11 March there were quantitative differences in plant growth between treatments (Table 2). Assessments conducted on 11 March and 22 April showed a significant mound by soil cover interaction with the height of plants grown on flat ground with organic mulch significantly reduced $(P<0.05)$ compared with all other treatments. The pre-plant application of metalaxyl had no effect on plant growth $(P>0.05)$ except in the assessment conducted on 22 April, where the chemical improved plant growth $(P<$ $0.05)$ when applied to mounded soil with organic mulch. In this assessment, plant heights were $123 \mathrm{~cm}$ in mounded plots treated with organic mulch and metalaxyl, compared with $95 \mathrm{~cm}$ in mounded plots with organic mulch alone. The final assessment conducted on 20 May showed a significant mound by soil cover interaction with a significant increase in plant height $(P<0.05)$ in mounded plots with both organic and plastic mulch compared with mounded plots with bare soil. Plants grown on mounds with, and without, mulches and on flat ground with plastic mulch were taller $(P<0.05)$ than plants grown on flat ground with organic mulch or bare soil.

At the conclusion of the experiment, the use of mounds was shown to be very effective (Table 3 ) at reducing the incidence of root rot. The percentage of plants with root rot was significantly greater $(P<0.05)$ in plots where plants were grown on flat ground with either organic mulch or bare soil compared with plants grown on mounds. There was no difference in survival $(P>0.05)$ between plants grown on flat ground with plastic mulch and plants grown on mounds. The pre-plant application of metalaxyl granules had no effect $(P>0.05)$ on reducing the incidence of root rot. P. palmivora was recovered from all root rot-affected plants.

At fruit harvest, the more mature fruit was obtained from the larger more vigorous plants. Large differences in fruit number and fruit weight were recorded across the various treatments (Table 3). Fruit weight and number were significantly greater $(P<0.05)$ when harvested from plants grown on mounds, and on flat ground with plastic mulch, than plants grown on flat ground with organic mulch or bare soil. The greatest yield was obtained from plants grown on mounds with plastic mulch.

\section{Discussion}

Results of the evaluation of metalaxyl and potassium phosphonate demonstrated that papaya treated fortnightly with foliar applications of potassium phosphonate $(10 \mathrm{~g} / \mathrm{L})$ had the lowest incidence of Phytophthora root rot. However, potassium phosphonate applied at 5 and $10 \mathrm{~g} / \mathrm{L}$ caused some phytotoxicity on the foliage of papaya. Other researchers have reported sensitivity to potassium phosphonate in a range of horticultural crops (Pilbeam et al. 2000). The lowest concentration at which phytotoxicity has been reported is
$0.4 \mathrm{~g} / \mathrm{L}$ phosphonate on mandarins (Walker 1989) and azaleas (De Boer and Greenhalgh 1990). Rates of application need to be further evaluated to reduce the risk of phytotoxicity on papaya.

Of the methods of application tested in our experiment, foliar sprays of potassium phosphonate $(10 \mathrm{~g} / \mathrm{L})$ were more effective than soil drenches of potassium phosphonate (1 and $2 \mathrm{~g} / \mathrm{L}$ ) at controlling root rot and increasing plant survival. Ali et al. (1999) reported that foliar sprays and soil drenches with potassium phosphonate $(0.1-5.0 \mathrm{~g} / \mathrm{L})$ were equally effective in reducing the disease incidence and severity of P. cinnamomi on Pinus radiata seedlings. However, De Boer and Greenhalgh (1990) reported that soil drenches were more effective than foliar sprays against Phytophthora root rot of azalea (Rhododendron ponticum cv. Brides Bouquet), Thryptomene calycina and petunia (Petunia hybrida). Further research is needed to optimise the frequency and timing of applications of potassium phosphonate to maximise its efficacy in controlling Phytophthora root rot of papaya.

Metalaxyl has proven to be most effective against many Phytophthora-related root diseases in a range of high value crops (Erwin and Ribeiro 1996). Prior to the registration of potassium phosphonate in avocados, metalaxyl was widely used for Phytophthora root rot control (Pegg and Whiley 1987). However, under the high disease pressure experienced in our field experiment, the disease control achieved with metalaxyl was disappointing as it failed to provide an adequate level of root rot control. Its potential for use in the field was also considered much reduced where repeated applications of the chemical made it too costly.

In field situations where a soilborne disease is well established, growers are generally encouraged to create a growing environment which is more favourable for the host and less favourable for the pathogen. The duration of free water in the soil has a major influence on the development of Phytophthora-related disease, with long periods of wet soil favouring an increase in Phytophthora populations (Duniway 1979). Therefore, optimising vertical drainage should effectively reduce the period of soil saturation and subsequent damage due to disease (Duniway 1983). Improving soil drainage through mounding has been shown to be an important part of the integrated disease management strategy used in avocado orchards prone to attack by Phytophthora (Broadley 1992; Pegg and Whiley 1987). The use of mounds in our field experiment also achieved this result by reducing plant losses due to root rot and substantially increasing fruit yield.

Wide plastic mulch also reduced plant losses and increased fruit yield in both mounded and non-mounded situations. Katan (1981) referred to the use of transparent polyethylene sheets by Israeli workers as a means of solar heating and soil disinfestation for disease control. However, in our case, solar heating would have been at a minimum as the plastic sheets were painted white and were laid during the 
wet season, which is a period of low light intensity. The result we achieved was most likely due to reduced water infiltration into the soil. However, the cost of purchasing and laying plastic mulch, and environmental concerns regarding its disposal, are likely to make its use prohibitive.

The slow degradation of organic mulch requires intense microbial activity, which increases the competition with Phytophthora (Broadbent and Baker 1974). However, Shea and Broadbent (1983) reported that P. cinnamomi could be recovered from partly decomposed mulch. They postulated that leachates from these mulches may stimulate the formation of sporangia. In our research, organic mulch caused severe plant losses due to root rot and substantially reduced fruit yield in all but mounded plots. This result was most likely due to increased soil moisture retention and the positive influence this has on increasing disease development (Vawdrey et al. 2002). Future research will evaluate the integration of single-row mounds and foliar applications of potassium phosphonate for the management of Phytophthora root rot of papaya.

\section{Acknowledgements}

The authors thank Dennis Walker and Ellis Turner who provided the experimental sites on their properties, and the Queensland Fruit and Vegetable Growers and Horticulture Australia Limited for their financial contribution to this research.

\section{References}

Ali Z, Smith I, Guest GI (1999) Effect of potassium phosphonate on root rot of Pinus radiata caused by Phytophthora cinnamomi. Australasian Plant Pathology 28, 120-125.

Broadbent P, Baker KF (1974) Behaviour of Phytophthora cinnamomi in soils suppressive and conducive to root rot. Australian Journal of Agricultural Research 25, 121-137.

Broadley RH (1992) 'Protect your avocados.' Information Series QI 91031, Department of Primary Industries, Brisbane, Queensland.

Chay-Prove PM (2000) 'Papaw information kit, Agrilink series: your growing guide to better farming.' (Queensland Horticulture Institute, Department of Primary Industries: Brisbane, Queensland)

Cohen Y, Coffey MD (1986) Systemic fungicides and the control of Oomycetes. Annual Review of Phytopathology 24, 311-338. doi:10.1146/ANNUREV.PY.24.090186.001523

De Boer RF, Greenhalgh FC (1990) Efficacy of potassium phosphonate in controlling Phytophthora root rot of subterranean clover and ornamental plants in Victoria. Australasian Plant Pathology 19, $124-125$.
Duniway JM (1979) Water relations of water molds. Annual Review of Phytopathology 17, 431-460. doi:10.1146/ANNUREV.PY.17. 090179.002243

Duniway JM (1983) Role of physical factors in the development of Phytophthora diseases. In 'Phytophthora: its biology, taxonomy, ecology, and pathology'. (Eds DC Erwin, S Bartnicki-Garcia, PH Tsao) pp. 175-187. (APS Press: St Paul, MN)

Dunn J (2001) Mounding for Phytophthora control — getting the right shape. Papaya Post 2 \& 3, 13-15.

Erwin DC, Ribeiro OK (1996) 'Phytophthora diseases worldwide.' (APS Press: St Paul, MN)

Jeffers SN, Martin SB (1986) Comparison of two media selective for Phytophthora and Pythium species. Plant Disease 70, 1038-1043.

Katan J (1981) Solar heating (solarisation) of soil for control of soil-borne pests. Annual Review of Phytopathology 19, 211-236. doi:10.1146/ANNUREV.PY.19.090181.001235

Pegg KG, Whiley AW (1987) Phytophthora control in Australia. South African Avocado Growers Association Yearbook 10, 94-96.

Pilbeam RA, Colquhoun IJ, Shearer B, Hardy GEStJ (2000) Phosphite concentration: its effect on phytotoxicity symptoms and colonisation by Phytophthora cinnamomi in three understorey species of Eucalyptus marginata forest. Australasian Plant Pathology 29, 86-95.

Shea SR, Broadbent P (1983) Developments in cultural and biological control of Phytophthora diseases. In 'Phytophthora: its biology, taxonomy, ecology and pathology'. (Eds DC Erwin, S Bartnicki-Garcia, PH Tsao) pp. 335-350. (American Phytopathological Society: St Paul, MN)

Schwinn FJ, Staub T (1987) Phenylamides and other fungicides against Oomycetes. In: 'Modern selective fungicides, applications and mechanisms of action'. (Ed. L. Horst) pp. 295-273. (Longman Scientific and Technical: Essex, England)

Vawdrey LL (2001) Quantification of inoculum density of Phytophthora palmivora in soil and its relation to disease incidence in papaw in far northern Queensland. Australasian Plant Pathology 30, 199-204. doi:10.1071/AP01019

Vawdrey LL, Martin TM, De Faveri J (2002) The potential of organic and inorganic soil amendments, and a biological control agent (Trichoderma sp.) for the management of Phytophthora root rot of papaw in far north Queensland. Australasian Plant Pathology 31, 391-399. doi:10.1071/AP02050

Walker GE (1989) Phytotoxicity in mandarins caused by phosphorous acid. Australasian Plant Pathology 18, 57-59. doi:10.1016/01654896(89)90069-3

Received 24 March 2003, accepted 22 August 2003 